\title{
Efektivitas Penggunaan Media Courselab Dalam Meningkatkan Hasil Belajar Matematika Siswa
}

\author{
${ }^{1}$ Rizka \\ 2Muhazzab Said \\ 3Irma T \\ ${ }^{3}$ Institut Agama Islam Negeri (IAIN) Palopo \\ Jl. Agatis, Kel. Balandai, Kota Palopo, Sulawesi Selatan, Indonesia \\ E-mail:3irma t@iainpalopo.ac.id
}

\begin{abstract}
Courselab can be able to make the lessons more varied and fun, so that adds to the interest of students to participate in learning. This study aims to determine whether the use courselab effective in improving students' mathematics learning outcomes. This study is an experimental research conducted in class VIII MTs Guppi Tompe Luwu Utara. The samples are saturated sample consisting of all students of class VIII MTs Guppi Tompe consisting of two classes, namely class VIII A of 27 students (grade control) and VIII B class consisting of 22 students (experimental group). The instrument used is the achievement test. Descriptive analysis of pre-test the control class and experimental class was flat at 53.40 and 52.68. This means that both classes have the same level of learning outcomes. Meanwhile, the results of the descriptive analysis of post-test on the control and experimental classes are 55.55 and 76.77. Thus, it appears that the use of media courselab effective in improving learning outcomes math class VIII MTs Guppi Tompe.
\end{abstract}

Keywords: Instructional Media, Courselab, Learning Outcome, Mathematics.

\begin{abstract}
Abstrak
Media courselab diyakini mampu membuat pelajaran lebih menjadi variatif dan menyenangkan, sehingga menumbuhkan minat siswa untuk mengikuti pembelajaran. Penelitian ini bertujuan untuk mengetahui apakah penggunaan media courselab efektif dalam meningkatkan hasil belajar matematika siswa. Penelitian ini adalah penelitian eksperimen yang dilaksanakan di kelas VIII MTs Guppi Tompe Kabupaten Luwu Utara. Sampel yang digunakan adalah sampel jenuh yang terdiri dari seluruh siswa kelas VIII MTs Guppi Tompe yang terdiri dari dua kelas yakni kelas VIII A yang terdiri dari 27 siswa (kelas kontrol) dan kelas VIII B yang terdiri dari 22 siswa (kelas eksperimen). Instrumen yang digunakan adalah tes hasil belajar. Hasil analisis deskriptif pre-test pada kelas kontrol dan kelas eksperimen relatif sama yakni 53,40 dan 52,68. Artinya kedua kelas memiliki tingkat hasil belajar yang sama. Sementara itu, hasil analisis deskriptif post-test pada kelas kontrol dan eksperimen adalah 55,55 dan 76,77. Dengan demikian terlihat bahwa penggunaan media courselab efektif dalam meningkatkan hasil belajar matematika siswa kelas VIII MTs Guppi Tompe.
\end{abstract}

Kata Kunci: Media Pembelajaran, Courselab, Hasil Belajar Matematika. 


\section{Pendahuluan}

Pendidikan merupakan suatu kegiatan yang secara sadar dan disengaja, serta penuh tanggung jawab yang dilakukan oleh orang dewasa kepada anak sehingga timbul interaksi dari keduanya agar anak tersebut mencapai kedewasan yang dicita-citakan dan berlangsung terus menerus. Dengan pendidikan, diharapkan dapat mengubah pola pikir manusia untuk berusaha melakukan perbaikan dalam segala aspek kehidupan ke arah peningkatan kualitas diri. Namun pada kenyataanya dunia pendidikan saat ini mengalami berbagai masalah, salah satu masalah yang dihadapi dunia pendidikan kita adalah masalah lemahnya proses pembelajaran.

Dalam proses pembelajaran, siswa kurang didorong untuk mengembangkan kemampuan berfikir. Proses pembelajaran di dalam kelas lebih banyak diarahkan kepada kemampuan untuk menghafal informasi, otak siswa dipaksa untuk menghafal dan menumpuk berbagai informasi tanpa dituntut untuk memahami informasi yang diingatnya dan menghubungkanya dengan kehidupan sehari-hari. Akibatnya siswa akan kaya dalam teori namun miskin dalam pengaplikasianya.

Kedudukan matematika dalam dunia pendidikan sangat besar manfaatnya karena matematika adalah alat dalam pendidikan perkembangan dan kecerdasan akal, yang di dalamnya dipelajari hal-hal yang berhubungan dengan ide-ide dan konsep-konsep yang abstrak. Menyadari akan pentingnya matematika, seorang guru harus mampu meningkatkan minat siswa dalam belajar matematika agar hasil belajarnya meningkat yaitu dengan menciptakan lingkungan yang kondusif. Oleh karena itu, seorang guru harus mampu menggunakan metode mengajar yang tepat.

Penggunaan metode mengajar yang tepat, merupakan suatu alternatif mengatasi masalah rendahnya hasil belajar siswa terhadap pelajaran matematika. Salah satu caranya adalah dengan memasukkan materi pelajaran dalam bentuk media courselab. Karena media courselab diharapkan mampu menciptakan suasana belajar tersebut menjadi lebih menyenangkan dan tidak terlalu membosankan dibandingkan dengan metode pembelajaran dengan cara biasa terutama dalam pelajaran matematika. 
Media CourseLab merupakan piranti lunak, digunakan untuk menyusun bahan ajar multimedia berbasis e-learning (authorings tools e-learning) yang powerful dan mudah digunakan. Adanya media courselab pembelajaran dapat meningkatkan konsentrasi siswa, terjadi interaksi yang lebih hangat, pembelajaran bervariasi sehingga tidak membosankan, mempercepat pemahaman, dan memperlama daya ingat. Courselab ini membuat pelajaran lebih menjadi variatif dan menyenangkan, sehingga menumbuhkan minat siswa untuk mengikuti pembelajaran. Adapun keunggulan media courselab yaitu media courselab tersebut langsung bisa menarik word, PDF, vidio dan power point sedangkan kelemahan dari powerpoint yaitu powerpoint tersebut tidak bisa menarik langsung word, PDFdan vidio.

Penggunaan aplikasi courselab hampir sama dengan penggunaan aplikasi Microsoft Powerpoint, sehingga para pengajar yang sudah terbiasa membuat bahan ajar menggunakan microsoft powerpoint tidak akan menemukan kesulitan di dalam pembuatan bahan ajar menggunakan courselab ini. Pada era teknologi informasi dan komunikasi (TIK) seperti sekarang ini, media pembelajaran dalam bentuk media courselab merupakan salah satu media yang sangat penting untuk menunjang proses pembelajaran di sekolah. Media courselab pembelajaran berfungsi untuk memudahkan para guru untuk menyampaikan materi pelajaran di sekolah. Materi dalam media courselab dikemas dengan baik, kemudian di tampilkan melalaui $L C D$ dengan perantara komputer. Selain berisi tentang materi pelajaran, media courselab pembelajaran juga dapat membantu guru untuk menyampaikan dan mengkomunikasikan materi pelajaran di sekolah. Oleh karena itu media courselab pembelajaran tentu akan bermanfaat dalam proses pembelajaran.

Media courselab termasuk dalam media visual yaitu media berbentuk gambar, model, benda/alat yang dapat memberikan pengalaman visual yang nyata. Kelebihan dari media visual ini yaitu :

1. Lebih menarik karena ada gambar, sehingga memberikan pengalaman nyata untuk siswa.

2. Lebih mudah mengingat dengan visual peta konsep, maid mapping dan singkatan.

3. Media visual dapat memperlancar pemahaman (misalnya melalui elaborasi struktur dan organisasi) dan memperkuat ingatan siswa.

4. Visual dapat pula menumbuhkan minat siswa dan dapat memberikan hubungan antara isi materi pelajaran dengan dunia nyata. 
Sedangkan kekurangan dari media ini yaitu :

1. Akan terjadi kesulitan jika siswa mengalami masalah pada indra penglihatannya.

2. Siswa tidak akan memahami gambar jika gambar tidak jelas atau tidak sama dengan bentuk nyatanya.

3. Tidak dapat melayani siswa dengan gaya belajar auditif dan kinestetik.

4. Membutuhkan waktu yang lama untuk membuat gambar dan ketrampilan khusus menyajikan gambar sesuai wujud aslinya.

\section{Kerangka Teoretis}

Media pembelajaran courselab telah terbukti dapat meningkatkan hasil belajar siswa. Hal ini dapat dilihat dari beberapa penelitian yang sebelumnya telah dilakukan. Courselab dapat digunakan dalam pengembangan materi pada mata pelajaran IPS di SD Negeri Tapak Panekan Magetan dimana bahan ajar yang berbasis courselab layak digunakan untuk mendukung pembelajaran mata pelajaran IPS karena telah diuji kelayakannya oleh ahli media dan ahli materi pembelajaran dan dapat meningkatkan motivasi belajar siswa ${ }^{1}$. Selain itu, courselab juga berperan dalam meningkatkan hasil belajar siswa di SMKN 1 Kota Cimahi².

\section{Efektivitas Media Courselab}

S. Nasution (dalam subroto) menyatakan bahwa dalam pengajaran yang merupakan hasil proses belajar mengajar, efektivitas tergantung dari beberapa unsur ${ }^{3}$. Cara untuk mencapai hasil belajar yang efektif yaitu siswa harus dijadikan pedoman setiap kali membuat persiapan dalam mengajar. Berdasarkan hal tersebut dapat disimpulkan bahwa efektivitas merupakan kemampuan atau kesanggupan memilih dan mewujudkan satu tujuan secara tepat sehingga dapat memberikan hasil yang optimal. Efektivitas belajar berarti sejauh mana tingkatan keberhasilan yang dicapai dalam suatu pembelajaran sesuai dengan tujuan yang telah ditetapkan

\footnotetext{
1 Saiman, "Pengembangan Materi Berbasis Courselab Mata Pelajaran Ips Pokok Bahasan Menghargai Jasa Dan Peranan Tokoh Perjuangan Dalam Mempersiapkan Kemerdekaan Indonesia Kelas V Sd Negeri Tapak Panekan Magetan" (IKIP PGSD Madiun, 2010), http://www.ikippgrimadiun.ac.id/ejournal/sites/default/files/2_Saiman\%20\%26\%20Rini_ Pengembangan\%20EMateri\%20Berbasis\%20Courselab\%20Matapelajaran\%20IPS.pdf.

${ }^{2}$ Arif Sumardiono, "Implementasi Perangkat Lunak Courselab Untuk Meningkatkan Hasil Belajar Siswa Tentang Elektronika Di Smkn 1 Kota Cimahi” (UPI, 2013), http://aresearch.upi.edu/operator/upload/s_te_0809164_chapterv.pdf.

${ }^{3}$ Subroto, Proses Belajar Mengajar Di Sekolah (Jakarta: Rineka Cipta, 2002), 9.
} 
Association For Education and Communication Technology (AECT) mendefenisikan media yaitu segala bentuk yang dipergunakan untuk suatu proses penyaluran informasi. Sedangkan Education Association (NEA) mendefenisikan sebagai benda yang dapat dimanipulasi, dilihat, didengar, dibaca atau dibicarakan beserta instrumen yang dipergunakan dengan baik dalam kegiatan belajar mengajar, dapat mempengaruhi efektivitas program instruktional. $^{4}$

Media CourseLab merupakan piranti lunak, digunakan untuk menyusun bahan ajar multimedia berbasis e-Learning (authorings tools e-learning) yang powerful dan mudah digunakan. ${ }^{5}$ Penggunaan aplikasi courselab hampir sama dengan penggunaan aplikasi Microsoft Powerpoint, sehingga para pengajar yang sudah terbiasa membuat bahan ajar menggunakan microsoft powerpoint tidak akan menemukan kesulitan di dalam pembuatan bahan ajar menggunakan courselab ini. Pada era teknologi informasi dan komunikasi (TIK) seperti sekarang ini, media pembelajaran dalam bentuk media courselab merupakan salah satu media yang sangat penting untuk menunjang proses pembelajaran di sekolah. Media courselab pembelajaran berfungsi untuk memudahkan para guru untuk menyampaikan materi pelajaran di sekolah. Materi dalam media courselab dikemas dengan baik, kemudian di tampilkan melalaui lcd dengan perantara komputer. Selain berisi tentang materi pelajaran, media courselab pembelajaran juga dapat membantu guru untuk menyampaikan dan mengkomunikasikan materi pelajaran di sekolah. Oleh karena itu media courselab pembelajaran tentu akan bermanfaat dalam proses pembelajaran.

${ }^{4}$ Asnawir and M Basyiruddin Usman, Media Pembelajaran, 1st ed. (Jakarta: Ciputat Pers, 2002), 11.

5 Abdul Munif, "Pembuatan Bahan Ajar Multimedia Interaktif Menggunakan Authorings Tools Courselab," Pembuatan Bahan Ajar Multimedia, accessed June 20, 2014, http://www.vedcmalang.com/pppptkboemlg/index.php/artikel-coba-2/teknologi-

informasi/836-pembuatan-bahan-ajar-multimedia-interaktif-menggunakan-course-lab. 


\section{Hasil Belajar Matematika}

Belajar adalah proses perubahan tingkah laku individu melalui interaksi dengan lingkungan. Menurut pengertian ini, belajar merupakan proses. Belajar bukan hanya mengingat, menghafal, namun lebih luas dari itu, yakni mengalami. Hasil belajar bukan penguasaan hasil latihan melainkan perubahan kelakuan. ${ }^{6}$ Secara psikologis, belajar merupakan suatu proses perubahan yaitu perubahan tingkah laku sebagai hasil dari interaksi dengan lingkungannya dalam memenuhi kebutuhan. Perubahan-perubahan tersebut akan nyata dalam seluruh aspek tingkah laku.

Belajar ialah suatu proses usaha yang dilakukan seseorang untuk memperoleh suatu perubahan tingkah laku secara keseluruhan, sebagai hasil pengalamannya sendiri dalam interaksi dengan lingkungannya. ${ }^{7}$ Karena itu seseorang yang belajar tidak sama lagi jika dibandingkan dengan saat sebelumnya, karena ia lebih sanggup menghadapi kesulitan memecahkan masalah atau menyesuaikan diri dengan keadaan. Ia tidak hanya menambah pengetahuannya, akan tetapi dapat pula menerapkannya secara fungsional dalam situasi-situasi hidupnya. ${ }^{8}$

Dari beberapa pengertian tentang belajar tersebut, dapat disimpulkan bahwa belajar adalah suatu proses atau usaha yang dilakukan oleh seseorang guna memperoleh suatu perubahan tingkah laku dalam hidupnya secara keseluruhan, sebagai hasil atau pencapaian yang diperoleh sendiri berdasarkan proses interaksi dengan lingkungannya dalam memenuhi kebutuhannya seperti kecakapan, keterampilan dan sikap.

Setiap proses belajar mengajar selalu menghasilkan hasil belajar. Hasil belajar merupakan hasil dari suatu interaksi tindak belajar dan tindak mengajar. Dari sisi guru, tindak mengajar diakhiri dengan proses evaluasi hasil belajar. Dari sisi siswa, hasil belajar merupakan berakhirnya penggal dan puncak proses belajar. Hasil belajar, untuk sebagian adalah berkat tindak guru, suatu pencapaian tindak pengajaran.

\footnotetext{
${ }^{6}$ Oemar Hamalik, Proses Belajar Mengajar, VI (Jakarta: Bumi Aksara, 2007), 28.

${ }^{7}$ Slameto, Belajar Dan Faktor Yang Mempengaruhinya (Jakarta: Rineka Cipta, 1995), 2.

${ }^{8}$ S Nasution, Didaktik Asas-Asas Mengajar, II (Jakarta: Bumi Aksara, 2000), 34-35.
} 
Pada bagian lain merupakan peningkatan kemampuan mental siswa. Definisi lain menyatakan bahwa hasil belajar adalah kemampuankemampuan yang dimiliki siswa setelah ia menerima pegalaman belajarnya ${ }^{9}$. Dalam sistem pendidikan nasional, rumusan tujuan pendidikan baik tujuan kurikuler maupun tujuan intruksional menggunakan klasifikasi hasil belajar dari benyamin bloom yang secara garis besarnya terbagi dalam tiga ranah yaitu ranah kognitif, ranah afektif, dan ranah psikomotoris. ${ }^{10}$

Berdasarkan hal tersebut dapat disimpulkan bahwa hasil belajar matematika merupakan kemampuan-kemampuan yang diperoleh dari proses belajar mengajar pada mata pelajaran matematika yang dapat dilihat dari setiap perubahan yang dialami siswa.

\section{Metode Penelitian}

Jenis penelitian yang digunakan dalam penelitian ini adalah penelitian eksperimen dengan menggunakan pendekatan pedagogik. Penelitian terdiri dari dua kelas yang dijadikan sampel penelitian. Kelas yang pertama disebut kelas eksperimen yang menggunakan media courselab dalam proses pembelajaran matematika dan kelas yang kedua menggunakan pembelajaran konvensional. Penelitian ini dilaksanakan di MTs. Guppi Tompe, kecamatan malangke Kabupaten Luwu Utara. Dimana, populasi dalam penelitian ini adalah siswa kelas VIII MTs. Guppi Tompe Kabupaten Luwu Utara yang terdiri atas dua kelas sebanyak 49 orang dan sekaligus menjadi sampel.

Variabel penelitian yang diamati dalam penelitian ini terdiri atas dua variabel yaitu variabel $\mathrm{X}$ yang dimaksud dalam penelitian ini adalah penerapan media courselab dan variabel $\mathrm{Y}$ adalah hasil belajar. Adapun desain penelitin yang digunakan seperti yang tampak pada Tabel 1 berikut:

${ }^{9}$ Nana Sudjana, Penilaian Hasil Proses Belajar Mengajar (Bandung: PT. Remaja Rosdakarya, 2008), 22.

${ }^{10}$ Ibid., 23. 
Tabel 1. Desain Penelitian

\begin{tabular}{|l|c|c|c|}
\hline \multicolumn{1}{|c|}{ Kelompok } & Pree-test & Perlakuan & Post-test \\
\hline Eksperimen (R) & $\mathrm{Y}_{1}$ & $\mathrm{X}_{1}$ & $\mathrm{Y}_{2}$ \\
\hline Kontrol (R) & $\mathrm{Y}_{3}$ & & $\mathrm{Y}_{4}$ \\
\hline
\end{tabular}

Keterangan :

$\mathrm{X}_{1}$ : Perlakuan dengan menerapkan pembelajaran media courselab.

$\mathrm{Y}_{1}$ : Hasil belajar matematika siswa kelas eksperimen sebelum perlakuan menerapkan pembelajaran media courselab.

$\mathrm{Y}_{2}$ : Hasil belajar matematika siswa kelas eksperimen setelah perlakuan menerapkan media courselab.

$\mathrm{Y}_{3}$ : Hasil belajar matematika siswa kelas kontrol sebelum pembelajaran.

$\mathrm{Y}_{4}$ : Hasil belajar matematika siswa kelas kontrol setelah pembelajaran.

Data peneltian ini terbagi menjadi data primer dan data sekunder. Data primer adalah data yang dikumpulkan langsung oleh peneliti yang bersumber dari kepala sekolah, guru, dan siswa. Sedangkan data sekunder adalah data yang diperoleh peneliti melalui pihak kedua atau tangan kedua seperti buku dan arsip-arsip sekolah.

Sebelum tes diberikan kepada siswa maka tes perlu divalidasi dan direliabilitas untuk mengetahui tingkat validitas dan reliabilitasnya dengan menggunakan statistik Aiken's V. Oleh karena semua populasi menjadi sampel penelitian maka tidak diadakn uji hipotesis, uji normalitas, homogenitas dan uji F.

Sedangkan kriteria yang digunakan untuk menentukan kategori hasil belajar matematika siswa MTs guppi tompe dalam penelitian ini adalah menggunakan lima kategori nilai hasil belajar seperti yang terlihat pada Tabel 2 berikut:

Tabel 2. Kategori Hasil Belajar Matematika

\begin{tabular}{|c|c|c|c|}
\hline Tingkat Penguasaan & Nilai akhir & Bobot & Interpretasi \\
\hline $90-100$ & $\mathrm{~A}$ & 4 & Memuaskan \\
\hline $80-89$ & $\mathrm{~B}$ & 3 & Baik \\
\hline $70-79$ & $\mathrm{C}$ & 2 & Cukup \\
\hline $60-69$ & $\mathrm{D}$ & 1 & Kurang \\
\hline$\leq 59$ & $\mathrm{E}$ & 0 & Gagal \\
\hline
\end{tabular}


Adapun Standar Kriteria Ketuntasan Minimal (SKKM) yang harus dipenuhi seorang siswa yang ada di MTs Guppi Tompe adalah 70 (SKKM ditentukan oleh pihak Sekolah). Jika seorang siswa memperoleh skor $\geq 70$ maka siswa yang bersangkutan mencapai ketuntasan individu, dan siswa yang memperoleh skor $<70$ maka siswa yang bersangkutan dinyatakan tidak tuntas. Peneliti mengambil data KKM ini dengan alasan bahwa jika pre-test yang peneliti lakukan sudah mencapai KKM, maka peneliti tidak melakukan tindakan dengan menerapkan media courselab. Ini berarti peneliti harus mengambil sampel lain atau lokasi penelitian lain. Jika nila pre-test belum mencapai KKM, maka penulis melanjutkan penelitian eksperimen dengan melakukan pengajaran dengan menggunakan media courselab dan dilanjutkan dengan post- test.

\section{Pembahasan}

Berdasarkan uji validitas pre test dan post test yang dilakukan oleh tiga orang validator diperoleh bahwa bail pre test maupun post test keduanya dinyakatan valid dengan indeks 3,63 dan 3,52 dimana telah memenuhi kategori kevalidan yaitu " $3,5 \leq \mathrm{M} \leq 4$ dikatakan sangat valid. Sedangkan uji reabilitas hasil analisis untuk soal pre-tes berada pada Derajat Agreements ( $\overline{d(A)})=0,90$ dan Derajat Disagreements $(\overline{d(D)})=0,1$. Sedangkan untuk hasil analisis soal post-test berada pada Derajat Agreements $(\overline{d(A)})=0,87$ dan Derajat Disagreements $(\overline{d(D)})=0,13$. Dengan demikian dapat disimpulkan bahwa soal pre-tes dan soal post-tes memiliki tingkat reliabel yang sangat tinggi.

Berdasarkan hasil analisis deskriptif data kelas kontrol untuk pemberian pre-tes diperoleh rata-rata $=53,40$, dimana 17 orang dengan persentase $63 \%$ siswa termasuk kategori gagal, 4 orang dengan persentase $15 \%$ siswa termasuk kategori kurang, 5 orang dengan persentase 19\% siswa termasuk kategori cukup, 1 orang dengan persentase 3\% siswa termasuk kategori baik. Jika nilai rata-rata tersebut disesuaikan dengan tabel 3.3 diperoleh informasi bahwa hasil belajar matematika awal siswa pada kelas kontrol memiliki predikat kurang.

Hasil perhitungan data kelas eksperimen untuk pemberian pre-tes diperoleh rata-rata $=52,68$ dimana adalah 12 orang dengan persentase $55 \%$ siswa termasuk kategori gagal, 5 orang dengan persentase $23 \%$ siswa termasuk kategori kurang, 4 orang dengan persentase $18 \%$ siswa termasuk kategori cukup, 1 orang dengan persentase 4\% siswa termasuk kategori baik. Jika nilai rata-rata tersebut disesuaikan dengan tabel 3.3 diperoleh informasi hasil belajar matematika awal siswa kelas eksperimen memiliki predikat kurang. 
Berdasarkan hasil pre-tes tersebut, maka penulis melakukan tindakan berupa pemberian pembelajaran dengan menerapkan media courselab di kelas eksperimen. Setelah diterapkan media courselab pada kelas eksperimen dan melihat hasil belajar matematika siswa dengan memberikan soal post-tes diperoleh nilai rata-rata 76,77; standar deviasi $(S)=8,630$; variansi $\left(\mathrm{S}^{2}\right)=74,470$. Jika nilai rata-rata tersebut disesuaikan dengan tabel 3.3 diperoleh informasi bahwa siswa pada kelas eksperimen memliki predikat baik. Sedangkan pemberian soal post-tes pada kelas kontrol yaitu kelas yang pembelajarannya tidak menerapkan media courselab diperoleh nilai rata-rata 55,55; standar deviasi $(S)=16,010$; variansi $\left(S^{2}\right)=256,333$. Jika nilai rata-rata tersebut disesuaikan dengan tabel 3.3 diperoleh informasi bahwa siswa pada kelas kontrol memliki predikat cukup.

Ini berarti dari kedua nilai hasil belajar matematika siswa tersebut, dapat disimpulkan bahwa hasil belajar matematika siswa pada post-tes kelas eksperimen dan kelas kontrol memilki perbedaan secara nyata. Berdasarkan hasil analisis statistik deskriptif yang dikonsultasikan dengan tabel pengkategorian, diperoleh bahwa kelas kontrol dan kelas eksperimen sebelum pembelajaran berkategori kurang. Sedangkan setelah pembelajaran, diperoleh bahwa kelas kontrol berada pada kategori gagal dengan rata-rata $=55,55$ dan kelas eksperimen setelah perlakuan sudah mencapai kategori baik dengan rata-rata $=76,77$. Jadi dapat disimpulkan bahwa hipotesis deskritif diterima. Dengan hasil tersebut, maka rata-rata hasil belajar matematika pada kelas eksperimen lebih baik dari pada rata-rata hasil belajar matematika kelas kontrol pada pokok bahasan relasi dan fungsi.

Berdasarkan hasil analisis tersebut, maka secara deskriptif diperoleh bahwa hasil belajar matematika siswa kelas VIII MTs Guppi Tompe sebelum diterapkan media courselab lebih rendah dari pada hasil belajar matematika sesudah diterapkan media courselab. Sehingga dapat disimpulkan bahwa terjadi perbedaan nilai hasil belajar matematika tersebut, salah satunya disebabkan adanya perbedaan perlakuan yaitu dengan menerapkan media courselab.

Sebelum menerapkan media courselab, keterlibatan siswa dalam proses belajar mengajar tidak terlalu nampak. Peran guru sangat dominan karena harus menjelaskan materi pelajaran secara tuntas. Hal ini mengakibatkan hanya sebagian kecil siswa yang terlihat aktif dalam pembelajaran. Siswa lebih banyak diam meski diberi kesempatan untuk mengajukan pertanyaan atau pendapat. Siswa hanya duduk mendengar guru berceramah dan menyalin penjelasan yang diberikan guru. siswa memiliki kecenderungan untuk menunggu jawaban dari guru. 
Dari hasil observasi yang dilakukan untuk melihat efektivitas siswa dalam menerima pelajaran dengan menggunakan daftar cek, dengan menerapkan pembelajaran media courselab pada kelas eksperimen lebih mendorong siswa untuk aktif dalam proses pembelajaran dengan terlibat langsung.

Pada pembelajaran dengan menerapkan media courselab siswa diberikan kesempatan bertanya, membahas suatu materi dan menyelidiki suatu masalah serta menemukan suatu konsep sehingga lebih aktif mengkontruksikan jawaban. Siswa diberikan kesempatan untuk menemukan suatu konsep yang diperlukan dalam memecahkan masalah sehingga belajar lebih bermakna dan siswa merasa termotivasi untuk belajar. Dengan demikian, peran guru tidak terlalu dominan. Guru berperan sebagai fasilitator dan motivator dalam proses belajar mengajar. Guru juga tidak mengajarkan matematika dalam bentuk jadi tetapi guru membimbing dan mengarahkan siswa menemukan konsep-konsep matematika.

Pada pertemuan pertama pembelajaran dengan penerapan media courselab dalam pelaksanaanya tedapat berbagai hambatan. Salah satu hambatan yang sangat terasa pada peserta didik yaitu adanya perubahan cara mengajar guru sehingga siswa perlu penyesuaian terhadap penerapan pembelajaran tersebut. Sehingga dalam menjawab relasi dan fungsi, siswa merasa sulit dalam mengerjakannya. Hal ini terjadi karena siswa terbiasa dengan penerapan pembelajaran yang telah diterapkan oleh guru.

Hambatan yang terjadi pada pertemuan pertama perlahan-lahan mulai berkurang pada pertemuan selanjutnya. Sehingga, siswa sudah mulai terbiasa belajar dan tertarik dengan menggunakan penerapan pembelajaran media courselab.

Berdasarkan hasil observasi pada kelas eksperimen mengenai aktivitas siswa dalam pembelajaran, pada pertemuan pertama awal hingga akhir menunjukkan adanya peningkatan aktivitas. Pada pertemuan-pertemuan awal masih banyak terdapat hambatan dalam pengelolahan pembelajaran tersebut, namun seiring berjalannya waktu peningkatan aktivitas siswa selama proses pembelajaran terus mengalami peningkatan pada pertemuanpertemuan selanjutnya. Adanya kekurangan dan hambatan dalam setiap pembelajaran segera ditindak lanjuti sehingga tidak mengurangi efektivitas pembelajaran. 
Berdasarkan hasil analisis statistik deskriptif yang diperoleh, cukup mendukung teori yang telah dikemukakan pada kajian teori dan hasil observasi yang dilakukan penulis dengan menggunakan penerapan media courselab, bila ditinjau dari keterlibatan siswa dalam proses pembelajaran dalam kelas eksperimen dengan melihat hasil pengamatan dari lembar observasi ternyata pembelajaran dengan menggunakan media courselab sangat membantu tercapainya hasil pembelajaran yang diinginkan, yaitu pembelajaran yang efektif, menarik minat siswa belajar matematika dan siswa dapat menemukan suatu konsep sehingga dapat menyelesaikan suatu masalah. Untuk lebih jelasnya dapat dilihat pada lampiran lembar pengamatan aktivitas siswa. Kegiatan belajar dilakukan dengan membekali siswa dengan berbagi ilmu pengetahuan, sehingga dengan pengetahuan tersebut siswa dapat sukses menjalani kehidupannya baik sekarang maupun di masa yang akan datang.

\section{Penutup}

Berdasarkan hasil analisis data diperoleh kesimpulan sebagai berikut:

1. Hasil belajar matematika siswa yang pembelajarannya tidak menerapkan media courselab memiliki nilai rata-rata $=53,40$ untuk pre-test, sedangkan untuk post-test memiliki nilai rata-rata $=55,55$.

2. Hasil belajar matematika siswa yang pembelajarannya menerapkan media courselab memiliki nilai rata-rata $=52,68$ untuk pre-test, sedangkan untuk post-test memiliki nilai rata-rata $=76,77$.

3. Berdasarkan hasil analisis diperoleh bahwa penerapan media courselab efektif dalam meningkatkan hasil belajar matematika siswa kelas VIII MTS Guppi Tompe, hal ini berarti bahwa terdapat perbedaan hasil belajar matematika siswa sebelum menerapkan media courselab dengan hasil belajar matematika siswa setelah menerapkan media courselab.

\section{Daftar Pustaka}

Asnawir, and M Basyiruddin Usman. Media Pembelajaran. 1st ed. Jakarta: Ciputat Pers, 2002.

Hamalik, Oemar. Proses Belajar Mengajar. VI. Jakarta: Bumi Aksara, 2007.

Munif, Abdul. "Pembuatan Bahan Ajar Multimedia Interaktif Menggunakan Authorings Tools Courselab." Pembuatan Bahan Ajar Multimedia. Accessed June 20, 2014. http://www.vedcmalang.com/pppptkboemlg/index.php/artikel-coba2/teknologi-informasi/836-pembuatan-bahan-ajar-multimediainteraktif-menggunakan-course-lab.

Nasution, S. Didaktik Asas-Asas Mengajar. II. Jakarta: Bumi Aksara, 2000.

Saiman. "Pengembangan Materi Berbasis Courselab Mata Pelajaran Ips Pokok Bahasan Menghargai Jasa Dan Peranan Tokoh Perjuangan Dalam Mempersiapkan Kemerdekaan Indonesia Kelas V Sd Negeri Tapak 
Efektivitas Penggunaan Media Courselab ...

Panekan Magetan." IKIP PGSD Madiun, 2010. http://www.ikippgrimadiun.ac.id/ejournal/sites/default/files/2_Saima n\%20\%26\%20Rini_Pengembangan\%20EMateri\%20Berbasis\%20Cour selab\%20Matapelajaran\%20IPS.pdf.

Slameto. Belajar Dan Faktor Yang Mempengaruhinya. Jakarta: Rineka Cipta, 1995.

Subroto. Proses Belajar Mengajar Di Sekolah. Jakarta: Rineka Cipta, 2002.

Sudjana, Nana. Penilaian Hasil Proses Belajar Mengajar. Bandung: PT. Remaja Rosdakarya, 2008.

Sumardiono, Arif. "Implementasi Perangkat Lunak Courselab Untuk Meningkatkan Hasil Belajar Siswa Tentang Elektronika Di Smkn 1 Kota Cimahi." UPI, $2013 . \quad$ http://aresearch.upi.edu/operator/upload/s_te_0809164_chapterv.pdf. 
Rizka, Muhazzab Said, \& Irma

Halaman ini sengaja dikosongkan

Al-Khwarizmi - 14 